\title{
ICC COURT DECISION ON REPARATION FOR VICTIMS OF THE POST-ELECTION VIOLENCE: NO REPARATION WITHOUT CONVICTION PROSECUTOR V. WILLIAM SAMOEI RUTO AND JOSHUA ARAP SANG, DECISION ON THE REQUEST REGARDING REPARATIONS, 1 JULY 2016
}

\author{
JOANNA MUSIAL-BUDNICKA *
}

On 1 July 2016, the Trial Chamber V(A) (Trial Chamber) ${ }^{1}$ of the permanent International Criminal Court (ICC) in its Decision on the Request regarding Reparations (Decision on Reparations) ${ }^{2}$, by majority held that the Trial Chamber cannot proceed further and decide on the reparation issues connected to the joint trial of Kenyan Deputy President William Samoei Ruto and co-accused, ex-journalist Joshua Arap Sang, both of whom faced charges of crimes against humanity for their suspected role in "post-election violence" that led to the deaths of approximately 1,000 persons and over 300,000 displaced persons. ${ }^{3}$ In its ruling, two of the three Trial Chamber judges, who terminated the Ruto and Sang case earlier on April 5, 2016 ${ }^{4}$, declined to consider the merits of the victims' views and concerns expressed by the Legal Representative of Victims - Wilfred Nderitu (LRV). ${ }^{5}$ Therein, the LRV

DOI: 10.1515/wrlae-2015-0042

* Master of Arts (Faculty of Law, Administration and Economics, Wroclaw University); LL.M. International and European Law (Radboud University Nijmegen); advocate; joanna.musial@gmail.com

${ }^{1}$ The ICC Trial Chamber V(A) included three Judges: Chile Eboe-Osuji (Presiding), Olga Herrera-Carbuccia and Robert Fremr.

2 Prosecutor $v$ William Ruto and Joshua Sang (Decision on the Request regarding Reparations) ICC-01/09-01/11-2038 (1 July 2016) (Decision on Reparations).

${ }^{3}$ Prosecutor $v$ William Ruto and Joshua Sang (Second Joint Submission by the Prosecution and the Defence as to Agreed Facts and the Authenticity of Evidence) ICC-01/09-01/11-653AnxA (15 March 2013); see also ICC-Case Information Sheet, Prosecutor $v$ William Ruto and Joshua Sang ICC-PIDS-CIS-KEN-01-012/14_Eng (14 April 2016).

${ }^{4}$ Prosecutor $v$ William Ruto and Joshua Sang (Decision on Defence Applications for Judgments of Acquittal) ICC-01/09-01/11-2027-Red (5 April 2016) (Decision Vacating the Charges), para 464.

5 Decision on Reparations (n 2) para 7; see Decision appointing a common legal representative of victims ICC-01/09-01/11-479 (23 November 2012), para 7. 
requested the Chamber (1) to establish that the Government of Kenya bears an obligation to provide reparations to victims of the post-election violence of 2007-2008 for various form of harm suffered and/or (2) to initiate and provide assistance for such victims through the Trust Fund for Victims (TFV) in accordance with its assistance programme. ${ }^{6}$ In other words, the LRV asked the Chamber to be part of the cause to award reparations and assist the victims of the 2007-2008 post-electoral violence in Kenya after collapse of the ICC's Ruto and Sang case. The majority of the Trial Chamber in its ruling reasoned that due to the fact that the Ruto and Sang case was terminated on the Defence Motion on "No Case to Answer", the Trial Chamber has no power to make any decision on the question of reparation in accordance to Article 75 of the Rome Statute for the benefit of the post-election violence victims. ${ }^{7}$ The Presiding Judge Chile Eboe-Osuji strongly dissented, ${ }^{8}$ explaining further his thinking on the question of reparations he provided earlier in the Reasons of Judge Eboe-Osuji. ${ }^{9}$ In his Dissenting Opinion, Judge Eboe-Osuji upraised a number of significant arguments supporting the view that the Court has legitimate power to address reparations for harm suffered to the victims as a result of crimes if such crimes have been found to have taken place but the persons standing trial for his participation in those crimes is not fund guilty. ${ }^{10}$ While the Dissenting Opinion of Judge Eboe-Osuji has no solid basis in the international criminal law documents, $\mathrm{i} n$ the eyes of the victims and the general public the majority Trial Chamber decision can be seen as the lost hope of being compensated for the suffered harm. This is due to the fact that the reparation principles arising from Article 75 (1) of the Rome Statute are based on the concept of individual criminal responsibility, rather than on the State's responsibility. Nevertheless, one of the aims of this article is to emphasise that the reparations provisions contained in the Rome Statute and the Rules of Procedure and Evidence are vague and that no overarching guidelines exist to assist the different Trial and Appeals Chambers to conduct efficient reparations proceedings. The adoption of principles in the Ruto and Sang case could simply clarified to an extent the reparation process in that case, even when these principles would not necessarily apply to future cases.

\footnotetext{
${ }^{6}$ Prosecutor $v$ William Ruto and Joshua Sang (Victims' Views and Concerns on the Issue of Reparation or Assistance in Lieu of Reparation Pursuant to the Trial Chamber Decision of 5 April 2016 on the Defence Motions on 'No Case to Answer' plus 3 annexes) ICC-01/0901/11-2035 (15 June 2016), para. 54 (Victims' Views and Concerns).

${ }^{7}$ Decision on Reparations (n 2) para. 7; see also Decision Vacating the Charges (n 4), para 149.

${ }^{8}$ Prosecutor $v$ William Ruto and Joshua Sang (Dissenting Opinion to Decision on the Requests regarding Reparations) ICC-01/09-01/11-2038-Anx (1 July 2016) (Dissenting Opinion of Judge Eboe-Osuji).

${ }^{9}$ Decision Vacating the Charges (n 4) - Reasons of Judge Eboe-Osuji 57.

${ }^{10}$ Dissenting Opinion of Judge Eboe-Osuji (n 8), paras 13-14, with reference to the Decision Vacating the Charges (n 4) - Reasons of Judge Eboe-Osuji 136.
} 
In such view, the majority decision is seen as a lost chance to clarify the law on the reparation issue in circumstances where the case was terminated on the no-case basis. In the lack of a specialised reparations Chamber, it is clear that the question of reparation following a trial (however concluded or terminated) falls to the Trial Chamber that conducted the relevant trial.

\section{INTRODUCTION}

On July 1, 2016, the ICC Trial Chamber V(A) (Trial Chamber) left without answers key questions on victims reparation central to the ICC's firstever Decision Vacating the Charges ${ }^{11}$, in which, by majority terminated the case against William Ruto and Joshua Sang. ${ }^{12}$ The International Criminal Court (ICC) has upheld that this Trial Chamber cannot take any decision on reparation issues correlated with the Ruto and Sang case under Article 75 of the Rome Statute because with the termination of the Ruto and Sang case the Chamber lost jurisdiction over that substance. Now, with this decision, the Court confirmed that conviction is a conditio sine qua non for any order for reparations issued by the Court, without the need to take into consideration the views and concerns of victims. While the Trial Chamber decision seems to be harmonious with the Court's legal framework, the Ruto and Sang case demonstrates that the procedural requirement of the reparation provision (Article 75 of the Rome Statute) may come into tension with the victims 'expectations to be compensated for the suffered harm. Tension between the procedural requirements of the reparation provision and the right to reparation for victims have arisen in the Decision Vacating the Charges, where the Presiding Judge Chile Eboe-Osuji ${ }^{13}$ concurred with the Judge Fremr' arguments. ${ }^{14}$ A debate has emerged whether the conviction of the accused is a precondition of reparation order given the fact that such interpretation would be dissatisfactory to the victims of 2007-2008 postelection violence. This is particularly significant, given that the termination of the case on the no-case basis signals an unfortunate turn in the search for truth and accountability for the violations experienced by Kenya's victims during post-election violence by the ICC.

This article lies important questions relating to reparations for which victims of post-election violence in Kenya have waited, and continue to wait. It involves two institutional players, the majority Trial Chamber and the victims represented by the common Legal Representative for Victims (LRV) supported by the Dissenting Judge Eboe-Osuji, with different mandates giving rise to different vision of the reparation system of the ICC. On the one hand, the Trial Chamber supported the general view that the reparation principles arising from Article 75(1) of the Rome Statute are based on the concept of individual criminal responsibility, rather than reparations based on

\footnotetext{
${ }^{11}$ Decision Vacating the Charges (n 4), para 464.

${ }^{12}$ Decision on Reparations (n 2), para 7.

${ }^{13}$ Decision Vacating the Charges (n 4) - Reasons of Judge Eboe-Osuji 58.

${ }^{14}$ Decision Vacating the Charges (n 4) - Reasons of Judge Fremr 3.
} 
state responsibility. On the other, Judge Eboe-Osuji in his opinion on the Ruto and Sang case, wondered aloud whether there may be "scope for the Court to require the Government to make adequate reparation to the victims of postelection violence." 15 The Judge proposed that a State's meddling in a prosecution - as Kenya has - could trigger the court's jurisdiction to issue an order of reparations against that State. He provided Article 4 (1) of the Rome Statute, as a legal basis for the Court to have "such legal capacity as may be necessary for the exercise of its functions and the fulfillment of its purpose." Taking these two views into consideration, the main question is whether the victims right to get reparation for the injury suffered cab be reconciled with the institutional obligation to be eligible only to order reparation when the person standing trial is found guilty? This article reflects fundamental tension within the requirements of the reparation order and the victims expectation to reparation for harm suffered.

\section{Promise of the ICC Prosecutor to Deliver the Justice FOR VICTIMS}

The issue arose, in December 2010, when the former Prosecutor of the ICC Luis Moreno Ocampo publicly announced named six suspects who according to Ocampo bore the highest responsibility for the crimes against humanity during 2007-2008 post-election violence in Kenya. ${ }^{16}$ Consequently, the Prosecutor established two separate cases, each containing three suspects. The first case was directed against the Minister of Agriculture William Samoei Ruto, Orange Democratic Movement chairman, Henry Kiprono Kosgey as well against the radio broadcaster, Joshua Arap Sang. ${ }^{17}$ The second case included the head of the Public Service, Francis Kirimi Muthaura, Deputy Prime Minister, Uhuru Muigai Kenyatta and the former Commissioner of Police, Mohammed Hussein Ali. ${ }^{18}$ The Pre-Trial Chamber II of the Court delivered summonses to appear for six suspects known as Ocampo six" on 8 March 2011. ${ }^{19}$ At the same time, ICC Luis Moreno

\footnotetext{
${ }^{15}$ Decision Vacating the Charges (n 4) - Reasons of Judge Fremr, para 208.

${ }^{16}$ ICC website: On 15 December 2010, the Office of the Prosecutor requested from Pre-Trial Chamber II to issue summonses to appear for six suspects in the Kenya situation: William Samoei Ruto, Henry Kiprono Kosgey, Joshua Arap Sang, Francis Kirimi Muthaura, Uhuru Muigai Kenyatta, Mohammed Hussein Ali, available at: <https://www.icccpi.int/kenya/rutosang\#2> accessed 1 July 2017.

${ }^{17}$ Prosecutor's Application Pursuant to Article 58 as to William Samoei Ruto, Henry Kiprono Kosgey and Joshua Arap Sang ICC-01/09-30-Red2 (15 December 2010).

${ }^{18}$ Prosecutor's Application Pursuant to Article 58 as to Francis Kirimi Muthaura, Uhuru Muigai Kenyatta and Mohammed Hussein Ali ICC-01/09-31-Red2 (15 December 2010).

${ }^{19}$ Prosecutor v Francis Kirimi Muthaura, Uhuru Muigai Kenyatta and Mohammed Hussein Ali (Decision on the Prosecutor's Application for Summonses to Appear for Francis Kirimi
} 
Ocampo promised all victims, their families and the word that Kenya would be an example on how to provide justice for the victims. ${ }^{20}$ In his speech, the ICC Prosecutor Ocampo said that "[t]hese were not just crimes against innocent Kenyans", but "[t]hey were crimes against humanity as a whole" and he promised that these prosecution would "break the cycle of impunity for massive crimes" and provide victims and their families with justice. ${ }^{21}$ But the ICC Court has delivered of none of the above promised. Charges have not been confirmed or were withdrawn relating to above-mentioned six suspects, including the termination of the latest Ruto and Sang case in $2016 .^{22}$ In its place, the hope for justice through conviction of two reminded accused, Mr. Ruto and Mr. Sang for victims and their families has been crushed.

\section{TERMination OF THE RUTO AND SANG CASE ${ }^{23}$ AND ITS IMPACT ON THE DECISION ON REPARATIONS}

As already said, on April 5, 2016, Trial Chamber delivered the Decision Vacating the Charges where majority judges, vacated the charges

\footnotetext{
Muthaura, Uhuru Muigai Kenyatta and Mohammed Hussein Ali) ICC-01/09-02/11-01 (8 March 2011); Prosecutor v William Samoei Ruto, Henry Kiprono Kosgey and Joshua Arap Sang (Decision on the Prosecutor's Application for Summons to Appear for William Samoei Ruto, Henry Kiprono Kosgey and Joshua Arap Sang) ICC-01/09-01/11-01 0 (8 March 2011).

${ }^{20}$ Lionel Nichols, The International Criminal Court and the End of Impunity in Kenya (Springer 2015) 82.

${ }^{21}$ Press Release: ICC-OTP, Kenya's post-election violence: ICC Prosecutor presents cases against six individuals for crimes against humanity, ICC-OTP-20101215-PR615 (15 December 2010).

${ }^{22}$ While the case initially involved six suspects (William Samoei Ruto, Henry Kiprono Kosgey, Joshua Arap Sang, Francis Kirimi Muthaura, Uhuru Muigai Kenyatta, and Mohammed Hussein Ali), on 23 January 2012, the Pre-Trial Chamber II did not confirm the charges against Mr. Ali and Mr. Kosgey. The majority judges of the Pre-Trial Chamber confirmed the charges against only four of six suspects on 23 January 2012 (against Ruto, Sang, Kenyatta and Muthaura). The "Ocambo six" became the "Ocampo four", see: Prosecutor $v$ William Ruto and Joshua Sang (Decision on the appeals of Mr William Samoei Ruto and Mr Joshua Arap Sang against the decision of Pre-Trial Chamber II of 23 January 2012 entitled "Decision on the Confirmation of Charges Pursuant to Article 61(7)(a) and (b) of the Rome Statute") ICC-01/09-01/11-414 (24 May 2012); see Prosecutor v Francis Kirimi Muthaura, Uhuru Muigai Kenyatta (Decision on the appeal of Mr Francis Kirimi Muthaura and Mr Uhuru Muigai Kenyatta against the decision of Pre-Trial Chamber II of 23 January 2012 entitled "Decision on the Confirmation of Charges Pursuant to Article 61(7)(a) and (b) of the Rome Statute") ICC-01/09-02/11-425 (24 May 2012). Later on, the OTP withdraws charges against Muthaura on 11 March 2013; see Prosecutor v Francis Kirimi Muthaura and Uhuru Muigai Kenyatta (Prosecution notification of withdrawal of the charges against Francis Kirimi Muthaura) ICC-01/09-02/11-687 (11 March 2013). Further, the Trial Chamber V (B) terminated the proceedings against Mr. Kenyatta on 11 March 2015. Charges were withdrawn because of the insufficient evidence; see Prosecutor v Uhuru Muigai Kenyatta (Decision on the withdrawal of charges against Mr Kenyatta) ICC-01/09-02/111005 (13 March 2015).

${ }^{23}$ The trial of Mr. Ruto and Mr. Sang was opened on 10 September 2013. They were accused of crimes against humanity allegedly committed in the 2007-2008 post-election violence in Kenya. On 5 April 2016, the Trial Chamber V (A) decided, by majority to terminate the case against Ruto and Sang. The parties of the case did not appeal this decision.
} 
against the latest two accused from "Ocampo six"- Mr. Ruto and Mr. Sang, "without prejudice to their prosecution afresh in future". ${ }^{24}$ When the Prosecution finished its case, the Defence demanded the Chamber to end the case and acquit the accused on account of the weak Prosecution evidence. ${ }^{25}$ The Chamber, by majority, after a review of the Prosecution evidence, ruled that the Prosecutor had failed to present sufficient evidence linking Ruto and Sang to the direct perpetrators of the crimes. Consequently, neither of the two accused have a case to answer under the Prosecution charges. ${ }^{26}$ The standard result of a conclusion that there is "no case to answer" 27 for the accused would be an acquittal. However, by reasons of the evidence and submissions presented to the Chamber, the majority of judges determined that the judgment of the acquittal was not a good solution and only the vacation of the charges could take place. ${ }^{28}$ Due to the Ruto and Sang case ended without a conviction, the majority assumed that the reparations order cannot be made by this Court in accordance to Article 75 of the Rome Statute for the victims of the 2007-2008 post-election violence in Kenya. ${ }^{29}$ Furthermore, the majority of the judges concluded in one sentence that even though the judgment is dissatisfactory to the victims, the Court can only recompense for harm suffered as a consequence of crimes for which the person standing trial has been found guilty. ${ }^{30}$ Judge Eboe-Osuji in his reasoning, disagreed with the majority's interpretation. He said that it would be equally "unnecessary and undesirable that a conviction is a prerequisite to reparation" 31 precisely

\footnotetext{
${ }^{24}$ Decision Vacating the Charges (n 4) 1.

25 ibid 1.

${ }^{26}$ In reaching its decision, the Trial Chamber invoked the Article 64 (2) of the Rome Statute which enforces the obligation upon the Trial Chamber to conduct the fair and expeditious trial. The Trial Chamber established that "there is no provision in the ICC basic documents that requires a Trial Chamber to continue with the presentation of evidence on behalf of the defence, where the evidentiary case for the prosecution was not strong enough to warrant inviting the defence to present their case"; see Decision Vacating the Charges (n 4), para 146. 27 "The Statute and Rules do not currently explicitly provide for 'no case to answer' submission. However, Article 64 (3) (a) of the Statute sets out that the Chamber shall "[c]onfer with the parties and adopt such procedures as are necessary to facilitate the fair and expeditious conduct of the proceedings". It has also been correctly suggested that the Chamber could entertain 'no case to answer' motions pursuant to its power to decide on any other relevant matter, as contained in Article 64(6)(f) of the Statute. Similarly, Rule 134 of the Rules confers broad powers on the Chamber to rule on 'any issue concerning the conduct of the proceedings' and on 'issues that arise during the course of the trial'. These provisions grant the Chamber the necessary authority to consider 'no case to answer' motions in appropriate circumstances."; see in: Prosecutor v William Ruto and Joshua Sang, Decision No. 5 on the Conduct of Trial Proceedings (Principles and Procedure on 'No Case to Answer' Motions) ICC-01/09-01/11-1334 (3 June 2014), para 13.

${ }^{28}$ Decision Vacating the Charges (n 4) - Reasons of Judge Fremr 55.

${ }^{29}$ ibid, para 149.

${ }^{30}$ ibid, para 149.

${ }^{31}$ Decision Vacating the Charges (n 4) - Reasons of Judge Eboe-Osuji 136-138.
} 
that no one should doubt that the post-election violence took place and that such violence caused serious harm to victims. ${ }^{32}$ In the given case, the parties never challenged the incidence of the post-election violence ${ }^{33}$ and the overall findings of the Waki Commission in this respect (Waki Report). ${ }^{34}$ The evidential difficulty was only relating to the responsibility of Ruto and Sang for that violence. In such situations, how it could happen that the victims of the post-election are left with no reparation right for their harm? ${ }^{35}$ Under the circumstances of the Ruto and Sang case, the Judge clearly reflected that there are legal grounds both in international law and national laws which reject the „no compensation without conviction” doctrine. ${ }^{36}$ A representative norm in this regard is presented in the European Convention on Compensation Victims of Violent Crimes. It provides in Article 2 (1) that when compensation is not fully available from other sources, the State shall contribute to compensate victims (and their survivors) for serious injuries occasioned by malicious crimes of violence. ${ }^{37}$ And, more importantly for present purposes, the Convention provides in Article 2 (2) that "[c]ompensation shall be awarded in the above cases even if the offender cannot be prosecuted or punished." Further, in his opinion Judge Eboe-Osuji pointed the criminal injuries compensation schemes in many national jurisdictions which do not require conviction as a prerequisite to reparation. ${ }^{38}$ The footnote for this statement cites New Zealand, Ontario (Canada), the United Kingdom, and Western Australia. In this regard, he suggested that Article 4 (1) provides the Rome Statute with jurisdiction to make determinations of State responsibility - even if only for the purposes of reparations decisions, further confined to the limited set of cases where there is clear evidence of State interference. That being the case, the Judge emphasised that right of the victims to reparation should be addressed because the termination of the case "were polluted by undue interference and political meddling". ${ }^{39}$ The termination of the case in such circumstances should not hinder the victims' right to reparation or as a matter of the obligation of Kenya or the international community. ${ }^{40}$ In the view of Judge Eboe-Osuji, this is not only the State responsibility but also of international community to react on the harm suffered by the victims of the post-election violence by recognizing the victims' right to reparation. ${ }^{41}$ While this would be a welcoming move to

\footnotetext{
32 ibid, para 196.

${ }^{33}$ Prosecutor $v$ William Ruto and Joshua Sang (Second Joint Submission by the Prosecution and the Defence as to Agreed Facts and the Authenticity of Evidence) ICC-01/09-01/11-653AnxA (15 March 2013).

${ }^{34}$ Report of the Commission of Inquiry into Post-Election Violence, EVD-T-OTP-00328, 347.

${ }^{35}$ Decision Vacating the Charges (n 4), para 198.

${ }^{36}$ Dissenting Opinion of Judge Eboe-Osuji (n 8), para 13; Decision Vacating the Charges (n 4), para 201.

${ }^{37}$ ibid.

${ }^{38}$ Dissenting Opinion of Judge Eboe-Osuji (n 8), para 13; Decision Vacating the Charges (n 4), para 201.

${ }^{39}$ Decision Vacating the Charges (n 4), paras 199-200 and para 464.

${ }^{40}$ Decision Vacating the Charges (n 4) - Reasons of Judge Eboe-Osuji 61.

${ }^{41}$ ibid.
} 
victims in Kenya, Judge Eboe-Osuji's proposal would also significantly expand the powers of the court implicit in the Rome Statute, to include the power which is given to human rights institutions. This would undoubtedly trigger concern from the States Parties that may feel this is beyond the scope of an International Criminal Tribunal, which is only created to prosecute individuals for violations of international crimes. It also seems unlikely that the government of Kenya would be willing to deliver reparations that are ordered by the ICC.

In this regard, the Judge Eboe-Osuj invited victims to present their views and concerns with regard to reparation or assistance in lieu of reparation. Consequently, the LRV filed the Victims' Views and Concerns on the Issue of Reparation or Assistance in Lieu of Reparation Pursuant to the Trial Chamber Decision of 5 April 2016 on the Defence Motions on 'No Case to Answer' on 15 June 2016 (Victims' Views and Concerns). ${ }^{42}$

\section{VICTIMS' VIEWS AND CONCERNS}

In the Victims' Views and Concerns, the LRV agreed with the Judge Chile Eboe-Osuji on the issue that "there is no general principle of law that requires conviction as a prerequisite to reparation." ${ }^{, 43}$ It was argued that in the case with no conviction of the accused - reparations might be ordered through the Trust Fund for Victims, or against a third party (e.g., a State) on the basis of the obligation to provide reparations established in international law. ${ }^{44}$ The LRV argued that taking into consideration the specific circumstances in which the charges against the accused in this case were vacated, the right to reparation does not die with the decision vacating of the charges. ${ }^{45}$ Additionally, Kenya's failure to provide protection to the Kenyan population during the 2007-2008 post-election violence could considered as the violation of the international obligation of the State both erga omnes and as a treaty obligation under the Rome Statute. ${ }^{46}$ It is a general norm under Responsibility of States for Internationally Wrongful Acts that "[e]very internationally wrongful act of a State entails the international responsibility of that State". ${ }^{47}$

\footnotetext{
42 Victims' Views and Concerns (n 6). The Victims' Views and Concerns was consequential upon the invitation by the Presiding Judge of Chamber V(A), Judge Chile Eboe-Osuji, for victims to express their views and concerns in relation to reparation or assistance in lieu of reparation in the Judge's Reasons contained in the Decision on Defence Applications for Judgments of Acquittal, ICC-01/09-01/11-2027-Red (5 April 2016) 1.

${ }^{43}$ Decision Vacating the Charges (n 4), para 199.

${ }^{44}$ Victims' Views and Concerns (n 6), para 18.

45 ibid, para 21.

46 ibid, para 24.

${ }^{47}$ Responsibility of States for Internationally Wrongful Acts, 2001, available at:
} 
As such, Kenya had a obligation to defend its people and all other persons who found themselves on its territory, to protect its populations from genocide, war crimes, ethnic cleansing and crimes against humanity. ${ }^{48}$ Even the President Uhuru Kenyatta acknowledged officially on March $26^{\text {th }}, 2015$, the failure on the part of Kenya to prevent the violence and protect its population. ${ }^{49}$ In this regard, the LRV submitted also that Kenya as a State "meddled itself into the jurisdiction of the ICC" and should be obliged under international law to provide "adequate, effective and prompt reparation" to the sufferers of the post-election violence. ${ }^{50}$ In particular, the LRV stated that this obligation arises due to acts and omissions on the Government's part which amount to internationally illegal acts. The prevailing political situation in Kenya and the long passage of time since the incidence of the violence constitute two reasons that make reparations for victims merit urgent consideration. Accordingly, the LRV in the Victims' Views and Concerns asked the Trial Chamber first to establish that the Government of Kenya bears an obligation to provide reparation to victims of the 2007-2008 post-election violence for the harm suffered and second to make an order directed at the Trust Fund for Victims to provide assistance to all victims of the post-election violence in accordance with its assistance mandate. ${ }^{51}$

While the general principle of law requires a conviction as a prerequisite to reparations, the presented circumstances of the Ruto and Case case should not prevent the judges from entertaining questions of reparation in the absence of conviction. ${ }^{52}$ The majority determined however that LRV no longer have standing to make requests before the Trial Chamber in the background of the Ruto and Sang case. At the same time, the chance of clarifying the victim's right to reparation when the case is terminated on the no-case basis, has been lost.

\section{MAJority OF The TRIAL CHAMber V(A) VERSUS DisSENTING OPINION}

The Trial Chamber in the Decision on Reparations decided that those victims who took part in Kenya case will not receive compensation because no conviction has been made. ${ }^{53}$ The two in majority judges ${ }^{54}$ made no comments on the Victims' Views and Concerns on reparations, addressing that the Trial Chamber no longer has the jurisdiction to rule on that matter because the trial against Mr. Ruto and Mr. Sand was terminated on $5^{\text {th }}$ April

$<\underline{\text { http://legal.un.org/ilc/texts/instruments/english/draft articles/9 }} 6$ 2001.pdf $>$ accessed 1 July 2017.

48 Victims' Views and Concerns (n 6), para 24.

${ }^{49}$ ibid, para 26.

${ }^{50}$ ibid, para 46.

51 ibid, para 54.

${ }_{53}^{5}$ Dissenting Opinion of Judge Eboe-Osuji (n 8), para 12.

53 ibid, para 6.

${ }^{54}$ Judge Robert Fremr and Judge Olga Herrera Carbuccia. 
$2016 .{ }^{55}$ As a matter of fact, the Judges of the ICC dropped to consider a request by the LRV to determine if the Government of Kenya has an obligation to provide reparations to all victims of the 2007-2008 post-election violence for various form of harm suffered or order the Trust Fund for Victims to provide assistance to victims of the post-election violence. ${ }^{.56} \mathrm{In}$ that regard, the majority assumed that this Chamber is not the right place to entertain such views and concerns. ${ }^{57}$ Certainly, the Trial Chamber upheld a debatable reasons of Judge Fremr presented in the Trial Chamber Decision Vacating the Charges that as a consequence of the case ending with no conviction, the reparations order cannot be made by the Trial Chamber pursuant to Article 75 of the Rome Statute for the advantage of victims of the post-election violence. ${ }^{58}$ Even such decision is dissatisfactory to the victims, the ICC can only order compensation for harm suffered as an effect of crimes if such crimes are found to take place and the person standing trial is found guilty. ${ }^{59}$

Again, Judge Eboe-Osuji intensely disagreed with his colleague judges, providing in his Dissenting Opinion a quotation from 1989 dissenting opinion from US Supreme Court Judge A. Blackman, in which Judge Blackman charges the majority of retreating "into sterile formalism". 60 "With respect, I see no convincing basis in law for the idea that an ICC Trial Chamber may not entertain questions of reparation merely because the accused they tried was not found guilty," marked Judge Eboe-Osuji. ${ }^{61}$ In the view of Judge, such formal tactic could never supply a convincing system of reasoning that prevents the ICC Trial Chamber from considering the questions of reparations in the lack of conviction. ${ }^{62}$ What is even more important, the Judge Eboe-Osuji notices that unlike other international Tribunals as the ICTY and ICTR that have been "virtually exclusively concerned with punitive justice", the juristic circumstances of the ICC are more expansive in scope, "specifically because this Court's Statute actively recognises the need to administer reparative justice, too". ${ }^{63}$ The reparative system of the ICC requires that the aspect of reparation justice is given its own unique value, without unfair prejudice to the rights of accused. Everything less will be weaken the reparation system as an integral part of justice in the Court. ${ }^{64}$ Article 75 of the Rome Statute established principles

\footnotetext{
${ }^{55}$ Decision Vacating the Charges (n 4) 1.

${ }^{56}$ 'Victims' Views and Concerns (n 6), para 54.

${ }^{57}$ Decision on Reparations (n 2), para 7.

${ }^{58}$ Decision Vacating the Charges (n 4) - Reasons of Judge Fremr 56.

${ }^{59}$ Decision on Reparations (n 2), para 7; see Decision Vacating the Charges (n 4), para 149.

${ }^{60}$ Dissenting Opinion of Judge Eboe-Osuji (n 8), para 2.

61 ibid, para 12.

62 ibid.

${ }^{63}$ ibid, para 19.

64 ibid.
} 
concerning reparation for victims and there are no words of restriction that limit the circumstances in which those principles may be established. ${ }^{65}$ The circumstances do not prevent from the examination the termination of proceedings either upon an acquittal or on the basis that there is no case to answer at the end prosecution' case. ${ }^{66}$ In other words, because the decision to terminate the Ruto and Sang case was on the basis of "no case to answer" application, which was a first for the ICC, then it was necessary for the judges to have considered whether there were principles of reparation that could have been set for such a situation.

The Dissenting Opinion of Judge Eboe-Osuji can be seen as a call on the competent organs of the Court to develop and adopt clear principles on reparation in accordance with Article 75 of the Rome Statute. This could have helped to fill gaps in the ICC's basic reparation framework and helped to establish the guidelines which could assist the different Trial and Appeals Chambers to conduct efficient reparations proceedings in similar cases before the Court.

\section{Understanding THE REPARATIONS ISSUE BEFORE THE COURT}

Those who are lawyers can understand the legal reasoning presented by the majority of the judges presented in the Decision on Reparations. ${ }^{67}$ Article 75 of the Rome Statute is clear in as far as it requires a conviction of an accused person before the court can consider an award of reparations. The States Parties to the Rome Statute, by signing it, answered positively in Article 75 (2) that "[t]he Court may make an order directly against a convicted person specifying appropriate reparations to, or in respect of, victims, including restitution, compensation and rehabilitation" ${ }^{\circ 8}$ In this regard, the Rome Statute system is breaking new legal ground as its actors engage in an effort to order, fund, and implement reparations under the umbrella of international criminal law. Equally, the ad hoc Tribunals, the International Criminal Tribunal for the former Yugoslavia (ICTY) and the International Criminal Tribunal for Rwanda (ICTR) provided a structure where victims may seek reparations at the national level - in domestic courts, nonetheless it is doubtful if these kinds of resources ever exist in national organisations. ${ }^{69}$ However, as the Rwanda example shows, although damages were compensated in Rwanda as a consequence of proceedings in national law, they have yet not been imposed due to absence of funds at the national level. ${ }^{70}$

\footnotetext{
65 ibid, para 23.

66 ibid.

${ }^{67}$ Decision on Reparations (n 2), paras 6-7.

${ }^{68}$ Rome Statute of the International Criminal Court was adopted by the United Nations Diplomatic Conference of Plenipotentiaries on the Establishment of an International Criminal Court (17 July 1998) UN Doc. A/CONF.183/9 (Rome Statute).

${ }^{69}$ Victims may apply in a national court to obtain compensation in accordance to Rule 106 (b) of the Rules of Procedure and Evidence of the ICTY and ICTR.

70 REDRESS, 'Justice for Victims: The ICC's Reparations Mandate' (20 May 2011), available at: <http://www.refworld.org/docid/4def341618.html $>$ accessed 1 July
} 
These missed opportunities for awarding reparations for the ICTY/ICTR victims highlight the relevance and importance of the ICC's reparations system that learns from the ICTY and ICTR mistakes. While the presence of a provision on victim reparations in the ICC Rome Statute confers the responsibility on the ICC to afford justice to victims who suffered from the crimes committed by the accused, the trial on the reparations cannot take place until the conviction is achieved. ${ }^{71}$ In this regard, in 2012, the ICC's Trial Chamber I delivered its first-ever decision on reparations (TC Decision) pursuant to Article 75 of the Rome Statute in the Lubanga case authorizing collective reparations and making this order "through" the ICC Trust Fund. ${ }^{72}$ The Appeals Chamber's March 2015 judgment (Judgment on the appeals) partially overturned the TC Decision, but more relevant for the issue of reparation it established five fundamental elements of each reparation order. ${ }^{73}$ The Appeals Chamber explained that that the legal reparation order must contain, at a minimum, five necessary elements. These are: "1) it must be directed against the convicted person; 2) it must establish and inform the convicted person of his or her liability with respect to the reparations awarded in the order; 3) it must specify, and provide reasons for, the type of reparations ordered, either collective, individual or both, pursuant to rules 97 (1) and 98 of the Rules of Procedure and Evidence; 4) it must define the harm caused to direct and indirect victims as a result of the crimes for which the person was convicted, as well as identify the modalities of reparations that the Trial Chamber considers appropriate based on the circumstances of the specific case before it; and 5) it must identify the victims eligible to benefit from the awards for reparations or set out the criteria of eligibility based on the link between the harm suffered by the victims and the crimes for which the person was convicted." 74

In the Lubanga case, through the establishment of the five essential elements of the reparation order, the Appeals Chamber clarified a vision of

2017. 'Justice for Victims: The ICC's reparations mandate' (London 2011), 21; see Carla Ferstman, 'The Reparation Regime of the International Criminal Court: Practical Considerations' (2002) 15 Leiden Journal of International Law 667, 671.

${ }^{71}$ Sergey Vasiliev, International Criminal Procedure: Principles and Rules (UP Oxford 2013) 1359; see also: Christopher Muttukumaru, 'Reparations to Victims' in Roy S. Lee (ed), The International Criminal Court: The Making of the Rome Statute: Issues, Negotiations, Results (Kluwer 1999) 262, 264; William Schabas, An Introduction to the International Criminal Court (Cambridge University Press 2007) 137.

${ }^{72}$ Prosecutor $v$ Thomas Lubanga Dyilo (Decision establishing the principles and procedures to be applied to reparations) ICC-01/04-01/06-2904 (7 August 2012), paras 220-221 (TC Decision).

${ }^{73}$ Prosecutor $v$ Thomas Lubanga Dyilo (Judgment on the appeals against the 'Decision establishing the principles and procedures to be applied to reparations' of 7 August 2012 with AMENDED order for reparations (Annex A) and public annexes 1 and 2') ICC-01/04-01/063129 (3 March 2015), para 38 (Judgment on the appeals).

74 ibid, para 1 . 
the ICC that a reparation order need to be directed against the convicted person. ${ }^{75}$ It seems that the majority of the Ruto and Sang case have chosen to follow the same path. As a matter of fact the focal point of the ICC judicial reparation is the accent on punishing only those persons who have committed a wrong. The literary interpretation of the Article 75 of the Rome Statute, the case law of Lubanga and the Basic Principles and Guidelines on the Right to a Remedy and Reparation for Victims of Gross Violations of International Human Rights Law and Serious Violations of International Humanitarian $\mathrm{Law}^{76}$ evidently reiterate the requirement that the conviction is a prerequisite to reparation at the ICC. ${ }^{77}$ An order "cannot stand without a convicted person" because case of acquittal or a process otherwise ending without conviction does not allow for reparations". ${ }^{78}$ The ICC considers that reparations must reflect the context from which they arise, which, at the Court, is a legal system of establishing individual criminal liability for crimes under the Statute. This perspective strongly suggests that reparation orders are fundamentally connected to the individual whose criminal accountability is established in a conviction and whose liability for those criminal acts is regulated in a sentence. ${ }^{79}$

\section{Conclusions}

The Decision on Reparations is the first to determine that the ICC has no jurisdiction to order for reparations when the charges had been vacated and where in fact no case exists. In addition, this decision confirms the general principle that a conviction is a conditio sine qua non for each reparation' order issued by the Court which is compatible with the Court's governing legal framework. In its place, from the victim's perspective this must be dissatisfactory to the victims and their families waiting the long eight-years for justice and reparations. Victims of the 2007-2008 postelection violence in Kenya lost their hope. Charges were not confirmed or were withdrawn regarding all six suspects responsible for acts of postelection violence in Kenya. They did not get investigated court justice. The final verdict of the last two suspects, delivered in Ruto and Sang case, freeing them reoffered to the vision of "troubling incidence of witness interference and intolerable political meddling". This puts a shadow over the suspects

\footnotetext{
75 ibid, para 64.

76 'The Basic Principles and Guidelines on the Right to a Remedy and Reparation for Victims of Gross Violations of International Human Rights Law and Serious Violations of International Humanitarian Law', available at:

$<\underline{\text { http://www.ohchr.org/EN/ProfessionalInterest/Pages/RemedyAndReparation.aspx }>}$ accessed 1 July 2017.

${ }^{77}$ Vasiliev (n 71) 1366-1367.

${ }^{78}$ Prosecutor $v$ Thomas Lubanga Dyilo (Observations of the Trust Fund for Victims on the Appeals Against Trial Chamber I's 'Decision Establishing the Principles and Procedures to be Applied to Reparations') ICC-01/04-01/06-3009 (8 April 2013), para 109, citing Eva Dwertmann, The Reparation System of the International Criminal Court: Its Implementation, Possibilities and Limitations (Martinus Nijhoff Publishers 2010) 68-71.

${ }^{79}$ Judgment on the appeals (n 75), para 65.
} 
because the judges did not declare acquittal but rather set them free because the Office of the Prosecution did not provide the sufficient evidence upon which the Trial Chamber might convict the accused. While the majority decision that there are no pending proceedings related to the harm allegedly suffered by the victims of the post-electoral violence before this Court, ${ }^{80}$ has been taken in the light of the terms and background of the Rome Statute, such formalistic approach precludes the ICC Trial Chamber from entertaining answers of reparation in the lack of the conviction. ${ }^{81}$ The Judges decided on the issue of reparation without having listen to and considering the victims' submissions provided that the Trial Chamber is not the right forum to entertain [the victims'] views and concerns" ${ }^{\prime 82}$ on matters of reparation arising from termination of the case against Mr Ruto and Mr Sang. The Judges terminated the proceeding and the victims were not given a chance to express their views and concerns as to reparations which does not give individuals the full measure of their rights. Since the decision to terminate the Ruto and Sang case was based on the basis of no case to answer motions, the ICC first ever decision of this kind, then it seems that the Chamber should deliberate if any principles of reparations could be agreed in the given situation. Nevertheless, in order to set them, it is essential to reflect not only on the victims' views and concerns and on the TFV's submission, but also on the State Parties' applications. ${ }^{83}$ The Decision Vacating the Charges of April 5th was the first opportunity of its kind for the Court. The Decision on Reparations of July $1^{\text {st }}$ 2016 created a second one. Both chances have been wasted.

The termination of the Ruto and Sang case, at the ICC without ordering the reparation signs a new era, where there are no clear answers if the victims of post-election violence in Kenya will be compensated. It is the government of Kenya to take up its overdue primary responsibility of ensuring the victims compensation for the suffer harm. However, lack of political will in ensuring the compensation for victims has been very evident in Kenya. It took eight years for Kenya to admit the existence of the victims. This failure on the part of the State appears to have been recognized by President Uhuru Kenyatta during his State of the Nation Address on March, 26 2015, where the President made a public apology to the victims and promised to establish a 10 billion reparations fund. ${ }^{84}$ This has not been actualized to date. It indicates that a lot of commitment and political will is still required from the executive and judiciary to ensure the victims access and receive justice. Indeed, in this political scenario, it seems unfair that the Chamber has not considered whether there were principles of reparation that could have been set for the situation when the case has been terminated on

\footnotetext{
${ }^{80}$ Decision on Reparations (n 2), para 7.

${ }^{81}$ Dissenting Opinion of Judge Eboe-Osuji (n 8), para 12.

${ }^{82}$ Decision on Reparations (n 2), para 7.

83 ibid, para 24.

${ }^{84}$ Victims' Views and Concerns (n 6), para 26.
} 
the basis that although the crimes have been found to have taken place, the person standing trial for his participation in those crimes is not found guilty.

In the presented scenario, when the victims may not be compensated through the Court's order and when there is lack of the political will in Kenya, a clear path for assistance to victims in Kenya could be through the ICC's Trust Fund for Victims (TFV). The TFV already has a clear mandate from States Parties to provide physical, psychological, and material support to victims and their families, separately from, and prior to, a conviction by the court. The assistance from the TFV would not obviously relieve Kenya's authorities from its obligation under international law to provide reparation for victims. Under international law, States have a well-established legal duty to provide reparation for gross violations of international human rights law and serious violations of international humanitarian law. But the idea of TFV assistance for victims is distinct from the reparation and can be considered as a temporary solution for those victims who are in need of immediately help.

\section{References}

Decision appointing a common legal representative of victims ICC01/09-01/11-479 (23 November 2012).

Decision on Defence Applications for Judgments of Acquittal, ICC01/09-01/11-2027-Red (5 April 2016).

Dwertmann Eva, The Reparation System of the International Criminal Court: Its Implementation, Possibilities and Limitations (Martinus Nijhoff Publishers 2010).

Ferstman Carla, 'The Reparation Regime of the International Criminal Court: Practical Considerations' (2002) 15 Leiden Journal of International Law 667.

Muttukumaru Christopher, 'Reparations to Victims' in Roy S. Lee (ed), The International Criminal Court: The Making of the Rome Statute: Issues, Negotiations, Results (Kluwer 1999) 262.

Nichols Lionel, The International Criminal Court and the End of Impunity in Kenya (Springer 2015).

Press Release: ICC-OTP, Kenya's post-election violence: ICC Prosecutor presents cases against six individuals for crimes against humanity, ICC-OTP-20101215-PR615 (15 December 2010).

Prosecutor v Francis Kirimi Muthaura and Uhuru Muigai Kenyatta (Prosecution notification of withdrawal of the charges against Francis Kirimi Muthaura) ICC-01/09-02/11-687 (11 March 2013).

Prosecutor $v$ Francis Kirimi Muthaura, Uhuru Muigai Kenyatta (Decision on the appeal of Mr Francis Kirimi Muthaura and Mr Uhuru Muigai Kenyatta against the decision of Pre-Trial Chamber II of 23 January 2012 entitled "Decision on the Confirmation of Charges Pursuant to Article 61(7)(a) and (b) of the Rome Statute") ICC-01/09-02/11-425 (24 May 2012).

Prosecutor $v$ Francis Kirimi Muthaura, Uhuru Muigai Kenyatta and Mohammed Hussein Ali (Decision on the Prosecutor's Application for Summonses to Appear for Francis Kirimi Muthaura, Uhuru Muigai Kenyatta and Mohammed Hussein Ali) ICC-01/09-02/11-01 (8 March 2011); 
Prosecutor $v$ Thomas Lubanga Dyilo (Decision establishing the principles and procedures to be applied to reparations) ICC-01/04-01/062904 (7 August 2012).

Prosecutor $v$ Thomas Lubanga Dyilo (Judgment on the appeals against the 'Decision establishing the principles and procedures to be applied to reparations' of 7 August 2012 with AMENDED order for reparations (Annex A) and public annexes 1 and 2') ICC-01/04-01/06-3129 (3 March 2015).

Prosecutor v Thomas Lubanga Dyilo (Observations of the Trust Fund for Victims on the Appeals Against Trial Chamber I's 'Decision Establishing the Principles and Procedures to be Applied to Reparations') ICC-01/0401/06-3009 (8 April 2013).

Prosecutor v Uhuru Muigai Kenyatta (Decision on the withdrawal of charges against Mr Kenyatta) ICC-01/09-02/11-1005 (13 March 2015).

Prosecutor $v$ William Ruto and Joshua Sang (Decision on Defence Applications for Judgments of Acquittal) ICC-01/09-01/11-2027-Red (5 April 2016).

Prosecutor $v$ William Ruto and Joshua Sang (Decision on the appeals of Mr William Samoei Ruto and Mr Joshua Arap Sang against the decision of Pre-Trial Chamber II of 23 January 2012 entitled "Decision on the Confirmation of Charges Pursuant to Article 61(7)(a) and (b) of the Rome Statute") ICC-01/09-01/11-414 (24 May 2012).

Prosecutor $v$ William Ruto and Joshua Sang (Decision on the Request regarding Reparations) ICC-01/09-01/11-2038 (1 July 2016).

Prosecutor $v$ William Ruto and Joshua Sang (Dissenting Opinion to Decision on the Requests regarding Reparations) ICC-01/09-01/11-2038Anx (1 July 2016) (Dissenting Opinion of Judge Eboe-Osuji).

Prosecutor $v$ William Ruto and Joshua Sang (Second Joint Submission by the Prosecution and the Defence as to Agreed Facts and the Authenticity of Evidence) ICC-01/09-01/11-653-AnxA (15 March 2013).

Prosecutor $v$ William Ruto and Joshua Sang (Second Joint Submission by the Prosecution and the Defence as to Agreed Facts and the Authenticity of Evidence) ICC-01/09-01/11-653-AnxA (15 March 2013).

Prosecutor $v$ William Ruto and Joshua Sang (Victims' Views and Concerns on the Issue of Reparation or Assistance in Lieu of Reparation Pursuant to the Trial Chamber Decision of 5 April 2016 on the Defence Motions on 'No Case to Answer' plus 3 annexes) ICC-01/09-01/11-2035 (15 June 2016).

Prosecutor $v$ William Ruto and Joshua Sang ICC-PIDS-CIS-KEN-01012/14_Eng (14 April 2016).

Prosecutor $v$ William Ruto and Joshua Sang, Decision No. 5 on the Conduct of Trial Proceedings (Principles and Procedure on 'No Case to Answer' Motions) ICC-01/09-01/11-1334 (3 June 2014).

Prosecutor $v$ William Samoei Ruto, Henry Kiprono Kosgey and Joshua Arap Sang (Decision on the Prosecutor's Application for Summons to 
Appear for William Samoei Ruto, Henry Kiprono Kosgey and Joshua Arap Sang) ICC-01/09-01/11-01 0 (8 March 2011).

Prosecutor's Application Pursuant to Article 58 as to Francis Kirimi Muthaura, Uhuru Muigai Kenyatta and Mohammed Hussein Ali ICC-01/0931-Red2 (15 December 2010).

Prosecutor's Application Pursuant to Article 58 as to William Samoei Ruto, Henry Kiprono Kosgey and Joshua Arap Sang ICC-01/09-30-Red2 (15 December 2010).

REDRESS, 'Justice for Victims: The ICC's Reparations Mandate' (20 May 2011), available at: $<$ http://www.refworld.org/docid/4def341618.html $>$ accessed 1 July 2017.

Report of the Commission of Inquiry into Post-Election Violence, EVD-T-OTP-00328.

Request of the Office of the Prosecutor from Pre-Trial Chamber II to issue summonses to appear for six suspects in the Kenya situation: William Samoei Ruto, Henry Kiprono Kosgey, Joshua Arap Sang, Francis Kirimi Muthaura, Uhuru Muigai Kenyatta, Mohammed Hussein Ali (15 December 2010), available at: $<$ https://www.icc-cpi.int/kenya/rutosang\#2 $>$ accessed 1 July 2017. available

Responsibility of States for Internationally Wrongful Acts, 2001, $<$ http://legal.un.org/ilc/texts/instruments/english/draft articles/9 6 2001.pd f $>$ accessed 1 July 2017.

Rome Statute of the International Criminal Court adopted by the United Nations Diplomatic Conference of Plenipotentiaries on the Establishment of an International Criminal Court (17 July 1998) UN Doc. A/CONF.183/9.

Schabas William, An Introduction to the International Criminal Court (Cambridge University Press 2007).

The Basic Principles and Guidelines on the Right to a Remedy and Reparation for Victims of Gross Violations of International Human Rights Law and Serious Violations of International Humanitarian Law, available at: $<$ http://www.ohchr.org/EN/ProfessionalInterest/Pages/RemedyAndReparati on.aspx $>$ accessed 1 July 2017.

Vasiliev Sergey, International Criminal Procedure: Principles and Rules (UP Oxford 2013). 